\title{
Mutational and Functional Analysis of $F A N C B$ as a Candidate Gene for Sporadic Head and Neck Squamous Cell Carcinomas
}

\author{
MARCEL F. GLAAS ${ }^{1 *}$, CONSTANZE WIEK $^{1 *}$, LINDA-MARIA WOLTER ${ }^{1}$, \\ KATHARINA ROELLECKE ${ }^{1}$, VERA BALZ ${ }^{2}$, VERA OKPANYI ${ }^{1}$, MARTIN WAGENMANN ${ }^{1}$, \\ THOMAS KARL HOFFMANN ${ }^{3}$, RENE GRÄSSLIN ${ }^{3}$, CHRISTIAN PLETTENBERG ${ }^{1}$, \\ JÖRG SCHIPPER ${ }^{1}$, HELMUT HANENBERG $^{1,4^{*}}$ and KATHRIN SCHECKENBACH ${ }^{1 *}$ \\ ${ }^{1}$ Department of Otorhinolaryngology \& Head/Neck Surgery, \\ University Hospital Duesseldorf, Heinrich Heine University, Duesseldorf, Germany; \\ ${ }^{2}$ ITZ, Heinrich Heine University School of Medicine, Duesseldorf, Germany; \\ ${ }^{3}$ Department of Otorhinolaryngology \& Surgery (ENT), University School of Medicine, Ulm, Germany; \\ ${ }^{4}$ Department of Pediatrics III, University Children's Hospital Essen, University Duisburg-Essen, Essen, Germany
}

\begin{abstract}
Background/Aim: Head and neck squamous cell carcinomas (HNSCCS) form a heterogeneous tumor entity located throughout the oral cavity, pharynx and larynx that is caused predominantly by chemically or virally induced carcinogenesis. Heterozygous germline mutations in cancer susceptibility genes might also lead to increased incidence of HNSCCs. As DNA stability is typically impaired in HNSCC cells and genes of the Fanconi anemia/BRCA DNA repair pathway can be mutated or down-regulated in HNSCCs, we investigated here whether germline mutations occur in the X-chromosomal FANCB as candidate gene. Materials and Methods: Germline DNA of 85 consecutive HNSCC patients was sequenced. Missense alterations in FANCB were functionally tested in reference cells. Results and Conclusion: Four single nucleotide polymorphisms were identified, three of which were located in untranslated regions of FANCB (rs2188383, rs2375729, rs2905223) and predicted to be associated with normal function. One missense alteration, c.1004G>A resulting in p.G335E (rs41309679), in exon 4 was detected in five men in homozygous
\end{abstract}

This article is freely accessible online.

*These Authors contributed equally to this study.

Correspondence to: Dr. Helmut Hanenberg, Department of Pediatrics III, University Children's Hospital Essen, Hufelandstr. 55, D-45122 Essen, Germany. Tel: +49 2017231054, e-mail: Helmut.Hanenberg@uni-due.de or Dr. Kathrin Scheckenbach, Department of Otorhinolaryngology, University Hospital Duesseldorf, Moorenstr. 5, D-40225 Duesseldorf, Germany. Tel: +49 2118117570, e-mail: scheckenbach@med.uni-duesseldorf.de

Key Words: HNSCC, FANCB, genetic risk factors, sequencing, functional analysis. and in five women in heterozygous state. Four in silico prediction programs uniformally predicted p.G335E to be associated with loss-of-function of the protein. To clarify these predictions, we expressed the FANCB p.G335E protein in primary human FANCB deficient fibroblasts. Cell cycle analysis of these fibroblasts established that the FANCB p.G335E was functionally indistinguishable from the wildtype FANCB protein. Thus, functional studies in genetically defined cells showed that the p.G335E germline alteration in FANCB is not associated with impaired function.

Head and neck squamous cell carcinomas (HNSCCs) are the 6th most common type of cancers worldwide with varying rates in different ethnic populations (1-4). In the USA alone, over 60,000 new cases of HNSCCs are diagnosed and more than 13,000 patients die from HNSCCs each year (5). The tumor cells originate from the epithelium of the upper aerodigestive tract and undergo malignant transformation in a multistep process that is strongly influenced by an interplay between extrinsic (e.g. environmental or behavioral) and intrinsic (predominantly genetic) factors $(1,6)$. The four major cellular pathways implicated in the pathogenesis of HNSCCs are proliferation/survival, cell-cycle control, differentiation and adhesion/invasion signaling (7). The dysregulation of these pathways in the malignant cells is caused by somatic alterations/mutations in key genes such as TP53, HRAS, CCND1, NOTCH1 and others (7-9).

The major behavioral risk factors for the development of HNSCCs are increased consumption of tobacco, and alcohol, but also infection with oncogenic human papilloma virus (HPV) (1, $2,7)$. Several research groups including ours have established that a minority of patients with heterozygous germline mutations in known cancer susceptibility genes has an increased risk to develop HNSCC even in the absence of other behavioral risk 
factors. Among the genes mutated in the germline DNA of HNSCC patients are CDKN2A/p16 (10-12), the p16 interacting CDK4 (13), Killer/DR5 (14), PTEN (15), EGFR (16), and $R A D 51 C$ (17). However, it is noteworthy that a considerable overlap exists between genes that show somatic mutations in cancer and genes that predispose to the development of cancer by germline mutations $(7,18,19)$.

Fanconi Anemia (FA) is an inherited DNA repair disorder that is clinically characterized by congenital malformations, progressive bone marrow failure and a high propensity to develop malignancies (20). Importantly, SCCs of the head, neck, and esophagus and in women also vulvar and cervical cancers occur at astonishingly high rates in FA patients, up to $14 \%$ of patients by 40 years of age (21-23). This strongly suggests that defects in the FA pathway might increase the risk of developing HNSCCs. On a cellular level, defects in FA genes cause multiple defects including spontaneous genetic instability, hypersensitivity to DNA interstrand cross-linking agents, impaired selective autophagy, defective chromosome segregation and aneuploidy, hypersensitivities to oxidative stress and inflammatory cytokines as well as problems in telomere maintenance and replication (2429). All these cellular abnormalities promote malignant transformation of cells, thus explaining the high incidence of malignancies in FA patients. Genetically, FA is caused by lossof-function germline mutations in twenty-one DNA repair genes labelled $F A N C$ - $A / B / C / D 1 / D 2 / E / F / G / I / J / L / M / N / O / P / Q / R / S / T / U / V$ (30-32). Bi-allelic defects occur in 19 autosomal recessive FA genes, while single-allelic defects were described in the $\mathrm{X}$ chromosomal recessive $F A N C B$ in males (33) and in the dominant negative $R A D 51 / F A N C R(34,35)$ as responsible for the clinical and cellular abnormalities. Importantly, some FA genes (BRCA1/FANCS, BRCA2/ FANCD1, BRIP1/FANCJ, PALB2/FANCN, RAD51C/FANCO, XRCC2/FANCU) are also well-established cancer susceptibility genes, where heterozygous germline mutations in healthy individuals are associated with moderate to high risk to develop breast, ovarian, pancreatic and other tumors/malignancies (36-38).

The X-chromosomal FANCB gene product regulates $\mathrm{H} 3 \mathrm{~K} 9$ methylation on the sex chromosomes during meiosis and is essential for male fertility (39). The FANCB protein is part of the FA core complex located in the nucleus and has a scaffold function there (29). As a typical 'early' FA gene (29), FANCB-defective cells show an increased sensitivity towards DNA crosslinking agents and defective monoubiquitination of FANCD2 and FANCI, but are proficient for RAD51 foci formation and homologous recombination in the absence of crosslinker damage (33). In the past, a strong association between the development of HNSCCs and functional defects in FANCB was suggested, as the $F A N C B$ gene product is significantly down-regulated in sporadic HNSCCs (40) and up to $31 \%$ of sporadic HNSCC tumors and cell lines demonstrate hypermethylation in the FANCB locus (41). Therefore, the aim of this study
Table I. Characteristics of HNSCC patients enrolled in the germ line sequencing for FANCB.

\begin{tabular}{lc}
\hline Variable & No. patients \\
\hline Gender & 85 \\
Male & 65 \\
Female & 20 \\
Tumor location & \\
Oropharynx & 47 \\
Larynx & 17 \\
Hypopharynx & 9 \\
Nose and paranosal sinus & 8 \\
Oral cavity & 2 \\
Unknown primary (CUP) & 2 \\
Secondary tumor & \\
HNSCC & 11 \\
Larynx & 5 \\
Hypopharynx & 3 \\
Oropharynx & 2 \\
Lip & 1 \\
Other malignancy & 24 \\
Oesophageal cancer & 7 \\
Lung cancer & 4 \\
Bladder cancer & 4 \\
Prostate cancer & 3 \\
Colon cancer & 2 \\
CML & 1 \\
CLL & 1 \\
Mantle cell lymphoma & 1 \\
Mamma carcinoma & 1 \\
\hline
\end{tabular}

was to determine whether germline mutations in $F A N C B$ exist in sporadic HNSCC patients and, if detected, to characterize alterations predicted to influence the activity of the protein in functional assays.

\section{Materials and Methods}

Patients. The study enrolled 85 consecutive patients with histologically confirmed HNSCC from our clinic, including all sites (Table I) and stages $\left(\mathrm{T}_{1-4}, \mathrm{~N}_{0-3}, \mathrm{M}_{0 / 1}\right)$ of the disease. After obtaining informed consent, blood sample as a source of germline genomic DNA was drawn from each patient prior to treatment. Research was carried out in compliance with the Helsinki Declaration. This study was reviewed and approved by the ethics committee of the University of Duesseldorf, Germany.

Sequencing of FANCB exon 1-10. DNA was isolated from peripheral blood lymphocytes using a commercially available kit (Gentra Puregene Blood Kit, Qiagen, Hilden, Germany) as previously described $(17,42)$. All ten exons of the FANCB gene (Figure 1) were amplified in a standard PCR reaction using Taq PCR Master Mix Kit (Qiagen, Hilden, Germany) and primers (sequences are available from the Authors) located in the introns to amplify the 5', and 3' UTRs and all 10 exons including at least $50 \mathrm{bp}$ of the splice donor and acceptor sites. Sequencing was performed using an 


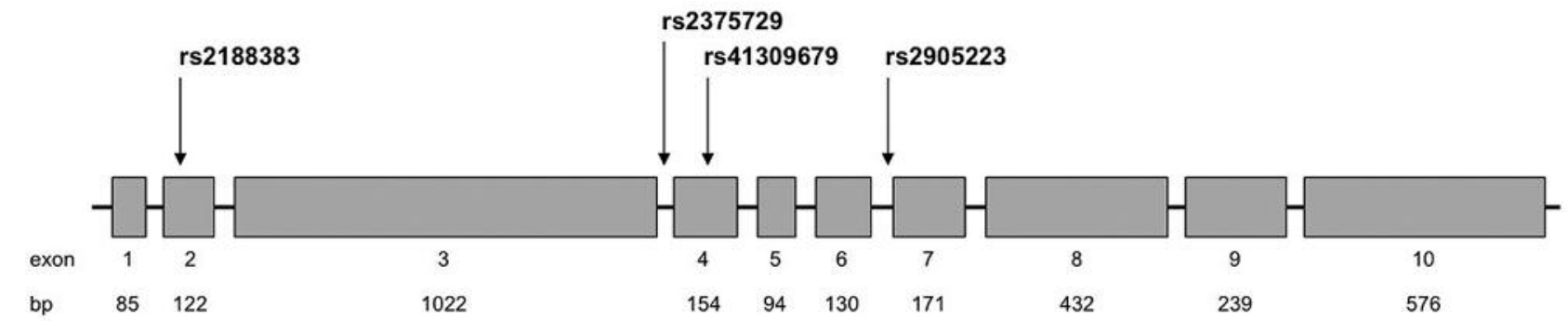

Figure 1. Genomic structure of FANCB with ten exons. The translational start is located in exon 3. SNPs found in this study are marked. (The intron/exon drawing is not according to scale).

3730x1 DNA Analyzer (Applied Biosystems/Thermo Fisher Scientific, Regensburg, Germany) as described previously (17).

Plasmid construction and lentiviral vector production. The retroviral and lentiviral vector backbones used in this study were described previously (42-44). The human codon-optimized cDNA for human wild-type (WT) FANCB cDNA was designed and then synthesized by GeneArt (Thermo Fisher Scientific). The cDNA was cloned with 5' SalI and 3' BamHI (New England BioLabs, Frankfurt, Germany) into the retroviral pS91-EGFP-IRES-NEO vector, thereby creating a fusion protein with 5' EGFP. For insertion of glutamic acid at position 335 in the human FANCB protein (p.G335E), a site-specific mutagenesis by standard overlap extension PCR was performed with the mutagenic primers 5'GTGCTGATCGACGACTTCATCGAAAGCGGCACCGAACAGG TGATG (forward) and 5'-CAGCACCTGTTCGGTGCCGCTTTC GATGAAGTCGTCGATCAGCAC (reverse) as described (42).

With the restriction endonucleases AgeI and BamHI, the EGFP$F A N C B$ WT and EGFP-FANCB G335E coding sequences were cloned into a lentiviral vector, puc2CL6EGIP, with an IRES-puro resistance gene cassette (Figure 2). All constructs were controlled by digestions and sequencing. Recombinant replication deficient lentiviral vectors were produced in the VSV-G pseudotype and primary human fibroblasts were transduced in the presence of 7.5 $\mu \mathrm{g} / \mathrm{ml}$ polybrene (Sigma-Aldrich, Deisenhofen, Germany) and the selected with $1 \mu \mathrm{g} / \mathrm{ml}$ puromycin (Sigma-Aldrich) as previously described $(43,44)$.

Cell cycle analysis of Mitomycin C (MMC)-treated primary fibroblasts. The healthy non-FA, FANCB- and FANCG-deficient reference fibroblasts were previously described by us (24). After selection with $1 \mu \mathrm{g} / \mathrm{ml}$ puromycin, stably transduced cells were incubated in the absence or presence of $45 \mathrm{nM}$ mitomycin $\mathrm{C}$ (MMC) at $5 \% \mathrm{CO}_{2}$ and normal oxygen levels at $37^{\circ} \mathrm{C}$ for three days. Cells were then harvested and prepared for flow-based cell cycle analysis as described previously (45). Briefly, cell pellets were resuspended in $1 \%$ bovine serum albumine (BSA; Sigma-Aldrich) in PBS, fixed with Ethanol and stored at $-20^{\circ} \mathrm{C}$ for at least $24 \mathrm{~h}$. Cells were then treated with $100 \mu \mathrm{g} / \mathrm{ml}$ RNase (Invitrogen, Karlsruhe, Germany) and stained with $10 \mu \mathrm{g} / \mathrm{ml}$ propidium iodine (Sigma-Aldrich). Subsequently, cells were analyzed on a FACSCalibur (BD Bioscience, Heidelberg, Germany) and 50,000-100,000 events collected for each sample. Analysis of the cell cycle distribution was performed using MODFITLT (Verity Software House, Topsham, Maine, USA).

\section{Results}

FANCB germline DNA mutational analyses were performed on 85 HNSCC patients (20 female and 65 male) between 32-75 years of age. Eleven patients had an independent secondary squamous cell carcinoma in the head and neck area, predominantly located in the larynx. Of those, five experienced an additional solid carcinoma (bladder, prostate, esophagus, colon, lung). Additional nineteen patients also developed an independent second malignancy elsewhere (see Table I for more information). Sequencing analysis of the DNA from peripheral blood leukocytes revealed the presence of four known single nucleotide polymorphisms (SNPs) within $F A N C B$, namely rs2188383 in exon 2, rs2375729 in intron 3, rs41309679 in exon 4, and rs2905223 in intron 6 (Figure 1, Table II).

The SNP rs2188383 was detected in 8 out of 20 females in heterozygous state and appeared homozygous in 22 out of 65 male patients due to the X-chromosomal location of $F A N C B$. As the translational start of FANCB is in exon 3 , this SNP is located within the 5'UTR region. The ancestral A of the rs2375729 in intron $3(c .951+129 A>C)$ is located outside of the active splice regions and was present in 7 out of 20 females and in 22 out of 65 males in 'homozygous' state; eight additional female patients were heterozygous carriers (Table II). The dbVAr database (https:// www.ncbi.nlm.nih.gov/dbvar) reports a minor allele frequency (MAF) of $47 \%$ for this SNP in the 1000 Genomes project. The SNP rs41309679 in exon 4 results in a glycine to glutamic acid exchange at amino acid 335 : c.1004G $>A$ leading to p.G335E (Figure 3). This SNP is present in only $4 \%$ of samples in the 1000 Genomes and in $6 \%$ in the ExAC database (Table II). The fourth SNP rs2905223 (c.1327$10 \mathrm{~T}>\mathrm{C}$ ) is located in intron 6 in the splice acceptor site and is relatively frequent in the 1,000 genomes $(0.4336)$ and in the ExAC (0.4362) databases. The human splicing finder algorithm (www.splicing.org) reported no significant alteration of the splicing for this SNP. 
control

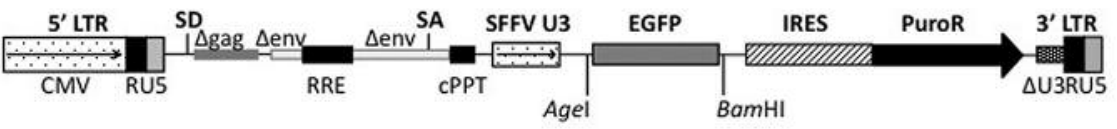

FANCB wt

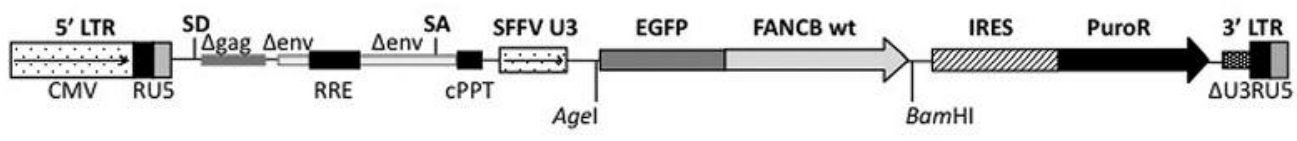

FANCB G335E

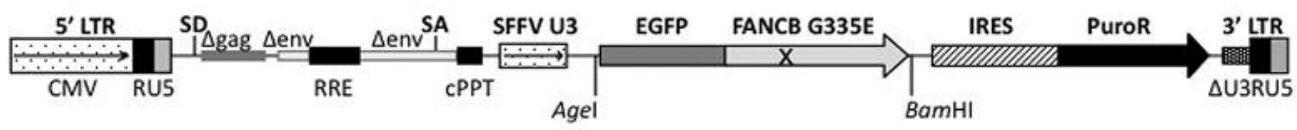

Figure 2. Scheme of the lentiviral vectors. The plasmid puc2CL6EGFBwtcoIP contains the human codon-optimized FANCB cDNA. All three plasmids carry an antibiotic resistance towards puromycin as selection marker and EGFP as a 5' protein tag.

For initial assessment whether the missense alteration p.G335E caused by rs41309679 might be associated with a loss-of-function in FANCB, we used four freely available online tools for analysis, namely PolyPhen-2 (http://genetics. bwh.harvard.edu/pph2/index.shtml), SIFT (http://sift.bii.astar.edu.sg/), MutationTaster (http://mutationtaster.org/) and Provean (http://provean.jcvi.org/index.php). Importantly, all four online tools predicted rs41309679 to be associated with loss-of-function (Table II), classified as 'probably damaging', 'deleterious' or 'disease causing'. As shown in Table III, the five homozygous carriers of rs41309679 were all male (3 laryngeal, 1 nasal and 1 oropharyngeal carcinoma), and the five heterozygous carriers ( 2 oropharyngeal, 2 hypopharyngeal and 1 laryngeal carcinoma) all females. One male had a secondary tumor in the oropharynx, one was also diagnosed with lung and bladders cancer and another experienced colon carcinoma. One female had a colon carcinoma. All 'homozygous' men smoked and four of the five regularly consumed alcohol. One woman regularly drank alcohol and smoked while four heterozygous female carriers did not report any behavioral risk factors. Data on HPV infections were not available. All females and half of the men showed metastasis to regional lymph nodes, however none of the affected patients had distant metastasis (Table III).

In order to ultimately determine whether these predictions for the missense alteration p.G335E were accurate, we decided to functionally test the amino acid substitution in FANCB by overexpression in primary $F A N C B$-deficient reference fibroblasts. The FA-typical hypersensitivity to relatively low concentrations of interstrand crosslinking agents can then be readily quantified by flow cytometrybased cell cycle analysis, a methodology that we have used extensively for functional analysis of missense mutations in reference primary cells and cell lines (45-47). To this end, we generated lentiviral vectors (Figure 2) containing either the wildtype or the p.G335E FANCB $c D N A s$ fused to EGFP.

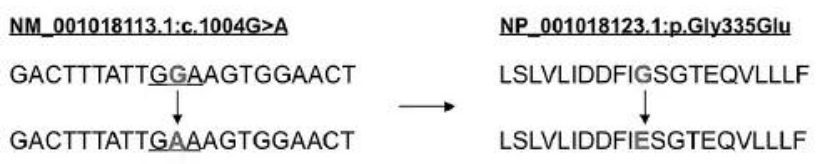

Figure 3. Missense alteration c.1004G $>$ A leading to p.G335E found in HNSCC patient \#67. The SNP rs41309679 changes glycine (GGA) at position 335 to glutamic acid (GAA).

In addition, the puromycin resistance gene pac was coexpressed from the same internal modified SFFV U3 promoter via an encephalomyelocarditis virus internal ribosomal entry site (IRES) $(43,44)$. The lentiviral vector plasmids were used to produce replication-deficient infectious lentiviral particles pseudotyped with the VSV-G envelope that we then titered by puromycin resistance on HT1080 cells as published previously (43, 44). After transfection, the presence of the FANCB-EGFP fusion proteins was confirmed in Western blots on HEK293T cells by staining with a commercially available EGFP monoclonal antibody and by using $\beta$-actin staining cells as a loading control (data not shown). Primary skin fibroblasts from a healthy donor and FANCG- and FANCB-deficient FA reference patients (24) were transduced with the three vectors shown in Figure 2 at multiplicities-of-infections of 1-2 for $24 \mathrm{~h}$. After selection with puromycin, stably transduced fibroblasts were challenged for three days with $45 \mathrm{nM}$ mitomycin $\mathrm{C}$ and then analyzed by flow cytometry (45-47). As shown in Figure 4, primary fibroblasts from a healthy donor did not arrest in the $\mathrm{G}_{2}$ phase of the cell cycle, while the control vector-transduced FANCG- and FANCBdeficient primary FA fibroblasts showed clear evaluations of their $\mathrm{G}_{2}$ peaks. Transduction with the wildtype and the p.G335E FANCB cDNAs both corrected the MMC-induced 
Table II. Results of germ-line DNA sequencing analysis. The sequence alterations found in 85 consecutive HNSCC patients are listed. SNP classification, the effect, the location, the distribution of the germ-line alterations in our study population of 20 females $(f)$ and 65 males $(m)$, the minor allele frequency $(M A F)$ in the 1000 Genomes project and in the Exome Aggregation Consortium (ExAC) are also shown. The prediction results of four algorithms for function classification of genomic alterations, namely PolyPhen-2 (http://genetics.bwh.harvard.edu/pph2/index.shtml), SIFT (http://sift.bii.a-star.edu.sg/), MutationTaster (http://mutationtaster.org/), Provean (http://provean.jcvi.org/index.php) as well as predictions of the Human Splicing Finder algorithm (http://www.umd.be/HSF/) are indicated.

\begin{tabular}{|c|c|c|c|c|c|c|c|c|c|}
\hline $\begin{array}{l}\text { SNP } \\
\text { effect } \\
\text { description }\end{array}$ & Location & $\begin{array}{l}\text { Own data } \\
\mathrm{f}=20, \mathrm{~m}=65 \\
(\mathrm{n}=85)\end{array}$ & $\begin{array}{l}\text { MAF: } 1000 \\
\text { genomes }\end{array}$ & $\begin{array}{l}\text { ExAC } \\
\text { data }\end{array}$ & PolyPhen2 & SIFT & $\begin{array}{l}\text { Mutation } \\
\text { taster }\end{array}$ & Provean & $\begin{array}{l}\text { Human } \\
\text { splicing } \\
\text { finder }\end{array}$ \\
\hline $\begin{array}{l}\text { rs } 2188383 \\
\text { c. }-173 \mathrm{G}>\mathrm{C}\end{array}$ & $\begin{array}{l}\text { Exon } 2 \\
\text { 5'UTR }\end{array}$ & $\begin{array}{c}\text { Cytosine: } 49 \\
\text { Guanine: } 28 \\
\text { Heterozygous: } 8\end{array}$ & $0.47(\mathrm{C})$ & $\begin{array}{c}\begin{array}{c}\text { Ancestral } \\
\text { allele: } \mathrm{G}\end{array} \\
\text { (not reported) } \\
\text { Cytosine: } 0.717 \\
\text { Guanine: } 0.283\end{array}$ & Unremarkable & Unremarkable & --- & --- & --- \\
\hline $\begin{array}{l}\text { rs } 2375729 \\
\text { c. } 951+ \\
129 A>C\end{array}$ & Intron 3 & $\begin{array}{c}\text { Cytosine: } 48 \\
\text { Adenine: } 29 \\
\text { Heterozygous: } 8\end{array}$ & $0.47(\mathrm{~T})$ & $\begin{array}{l}\text { Ancestral allele: A } \\
\text { (not reported) } \\
\text { Cytosine: } 0.717 \\
\text { (adenine: } 0.283\end{array}$ & $\begin{array}{l}\text { Splice } \\
\text { algorithms }\end{array}$ & $\begin{array}{c}\text { Splice } \\
\text { algorithms }\end{array}$ & --- & s & $\begin{array}{c}\text { No significant } \\
\text { splicing motif } \\
\text { alteration } \\
\text { detected }\end{array}$ \\
\hline $\begin{array}{l}\text { rs41309679 } \\
\text { c.1004G>A } \\
\text { p.G335E }\end{array}$ & Exon 4 & $\begin{array}{c}\text { Guanine: } 75 \\
\text { Adenine: } 5 \\
\text { Heterozygous: } 5\end{array}$ & $0.04(\mathrm{~T})$ & $\begin{array}{c}\text { Ancestral allele: } \mathrm{C} \\
\mathrm{T}=0.064\end{array}$ & $\begin{array}{c}\text { Probably } \\
\text { damaging (1) }\end{array}$ & Deleterious & $\begin{array}{l}\text { Disease } \\
\text { causing } \\
(0.999)\end{array}$ & $\begin{array}{c}\text { Deleterious } \\
(-6.864)\end{array}$ & $\begin{array}{l}\text { ESE Site } \\
\text { broken } \\
\text { Potential } \\
\text { alteration of } \\
\text { splicing }\end{array}$ \\
\hline $\begin{array}{l}\text { rs } 2905223 \\
\text { c. } 1327- \\
10 T>C\end{array}$ & Intron 6 & $\begin{array}{l}\text { Thymine: } 30 \\
\text { Cytosine: } 48 \\
\text { Heterozygous: } 7\end{array}$ & $0.43(\mathrm{G})$ & $\begin{array}{c}\text { Ancestral } \\
\text { allele: } \mathrm{A} \\
\mathrm{A}=0.4362 / 25946 \\
\text { Thymine: } 0.292 \\
\text { Cytosine: } 0.708\end{array}$ & --- & --- & --- & --- & $\begin{array}{c}\text { No significant } \\
\text { splicing motif } \\
\text { alteration } \\
\text { detected }\end{array}$ \\
\hline
\end{tabular}

Table III. Clinical characteristics of carriers of rs41309679 SNP enrolled in this study.

\begin{tabular}{|c|c|c|c|c|c|c|c|c|c|c|}
\hline Patient ID & T67 & $\mathrm{T} 78$ & $\mathrm{~T} 88$ & T156 & T174 & T51 & T56 & T84 & T117 & $\mathrm{T} 147$ \\
\hline Gender & Male & Male & Male & Male & Male & Female & Female & Female & Female & Female \\
\hline FANCB SNP & $\begin{array}{l}\text { Homo- } \\
\text { zygous }\end{array}$ & $\begin{array}{l}\text { Homo- } \\
\text { zygous }\end{array}$ & $\begin{array}{l}\text { Homo- } \\
\text { zygous }\end{array}$ & $\begin{array}{l}\text { Homo- } \\
\text { zygous }\end{array}$ & $\begin{array}{l}\text { Homo- } \\
\text { zygous }\end{array}$ & $\begin{array}{c}\text { Hetero- } \\
\text { zygous }\end{array}$ & $\begin{array}{l}\text { Hetero- } \\
\text { zygous }\end{array}$ & $\begin{array}{c}\text { Hetero- } \\
\text { zygous }\end{array}$ & $\begin{array}{l}\text { Hetero- } \\
\text { zygous }\end{array}$ & $\begin{array}{l}\text { Hetero- } \\
\text { zygous }\end{array}$ \\
\hline $\begin{array}{l}\text { Tumor } \\
\text { localisation } \\
\text { Age at }\end{array}$ & Larynx & Oropharynx & Nose & Larynx & Larynx & Oropharynx & Larynx & Hypopharynx & Hypopharynx & Oropharynx \\
\hline $\operatorname{HNSCC}(\mathrm{y})$ & 40 & 61 & 75 & 59 & 43 & 84 & 48 & 63 & 68 & 49 \\
\hline TNM & T1NxMx & $\mathrm{T} 2 \mathrm{~N} 1 \mathrm{M} 0$ & unknown & T1N0M0 & T4NxMx & T4N3Mx & $\mathrm{T} 1 \mathrm{~N} 2 \mathrm{aMx}$ & T3N2bM0 & T2N2bM0 & $\mathrm{T} 1 \mathrm{~N} 2 \mathrm{cMx}$ \\
\hline $\begin{array}{l}\text { Additional } \\
\text { cancers }\end{array}$ & No & $\begin{array}{c}\text { Colon } \\
\text { carcinoma }\end{array}$ & $\begin{array}{l}\text { Bladder, } \\
\text { lung }\end{array}$ & Oropharynx & No & No & No & $\begin{array}{l}\text { Oropharnyx } \\
\text { and Colon } \\
\text { carcinoma }\end{array}$ & No & No \\
\hline $\begin{array}{l}\text { Nicotin } \\
\text { consumption } \\
\text { Alcohol }\end{array}$ & Yes & Yes & Yes & Yes & Yes & No & No & No & No & Yes \\
\hline consumption & No & Yes & Yes & Yes & Yes & No & No & No & No & Yes \\
\hline
\end{tabular}

cell cycle arrest of the $F A N C B$-mutated fibroblasts to the levels of the normal control fibroblasts (indicated by the arrows). These results clearly demonstrated that despite the in silico prediction by four online tools, the p.G335E missense alteration in FANCB is associated with normal functions of the protein.

\section{Discussion}

Among the roughly 600,000 humans newly-diagnosed with HNSCCs each year worldwide, there is a pronounced gender disparity with the incidence in males being commonly 2 to 3 times higher in both, developed as well as developing 


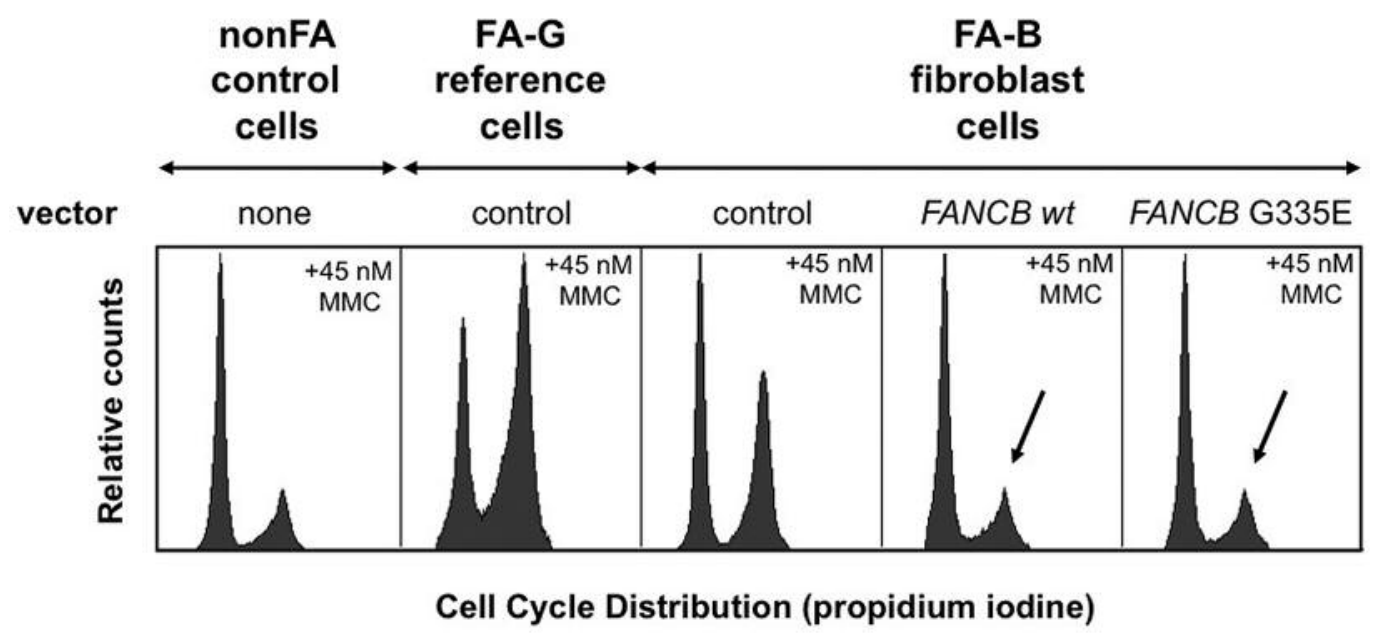

Figure 4. Cellular correction of primary FA-B fibroblasts by the FANCB p.G335E missense protein. Human primary FANCB-deficient fibroblast cells were analyzed by flow cytometry after three days in presence of mitomycin $C$.

countries (1). This phenomenon is also apparent in our patient cohort. Although it is commonly argued that men consume more tobacco and alcohol - the main behavioral risk factors for HNSCC development (1), it is tempting to speculate that inherited factors might also play an important role for this inbalance. Here, men would be at a major disadvantage if genetic risk factors for HNSCCs lie on the X-chromosome.

Myriads of studies have shown that lower or impaired DNA repair capacity strongly correlates with a higher risk to develop malignancies (reviews (48-50)). FANCB is a $\mathrm{X}$-chromosomal DNA repair gene with essential functions for DNA repair within the FA/BRCA pathway $(33,51)$ and it is also important for other functions in the cell $(39,52-54)$. Defects in FANCB are associated with genetic instability and hypersensitivity to DNA crosslinking agents such as platinumderivatives (33), both of which are also hallmarks of HNSCC cells. Remarkably, all FA patients including $F A N C B$ patients have an extremely high incidence of spontaneous HNSCCs (21-23). Importantly, other groups demonstrated that FANCB can be significantly down-regulated in sporadic HNSCC (40) and that up to $31 \%$ of sporadic HNSCC tumors demonstrate hypermethylation of the FANCB promoter locus (41).

We therefore decided to analyze germline DNA from 85 consecutive patients from our institution with histologically confirmed HNSCCs, including all sites and stages of the disease, by classical Sanger sequencing. Four different single-base nucleotide alterations were detected (Table II), one located in the 5' UTR in exon 2 and two located in introns 4 and 6, respectively. One alteration in exon $4, \mathrm{c} .1004 \mathrm{G}>\mathrm{A}$, is a missense substitution that leads to a substitution of glycine from glutamic acid (p.Gly335Glu) and therefore changes a small neutral amino acid to a larger acidic one. All four alterations were already present in the dbSNP public database at the National Center of Biotechnology at the National Institute of Health $(\mathrm{NIH})$ of U.S.A. (https://www.ncbi.nlm.nih.gov/snp). Two of the SNPs have previously been reported in Spanish patients from breast cancer pedigrees (55), however were not characterized or analyzed further. While the three untranslated SNPs have relatively high minor allele frequencies suggesting that they are functionally neutral, the missense alteration rs41309679 has a minor allele frequency of only 0.04 (Table II). In our patient cohort of 85 HNSCC patients, 10 patients were carriers of the germline missense alteration. Five out of these 10 patients were men and 'homozygous' for the SNP. All five females were heterozygous carriers. With respect to the behavioral risk factors, all men smoked and most of them drank alcohol, while 4 out of the 5 females neither smoked nor drank alcohol.

The p.G335E missense mutation changes both the polarity and size of the amino acid at this site in the protein and therefore could influence the correct folding as well as the functionality and stability of FANCB. Although four different web-based prediction programs, namely PolyPhen2, Sift Forecast, Mutation Taster and Provean, predicted that the missense will impair the functions of the FANCB protein ('probably damaging', 'deleterious' or 'disease causing'), we favored a functional approach for missense variation classification whenever possible. To this end, we established integrating viral vector systems to express cDNAs with missense variants of unknown significance of established or candidate DNA repair genes in genetically defined reference lines $(31,42,45,46)$. This approach is technically more advanced and requires proliferating cells with a cellular phenotype that can be corrected by overexpression of a normal cDNA of the altered gene. Here, we used a puromycin- 
selectable lentiviral vector to stably express an EGFP-tagged wild-type or p.G335E altered FANCB protein in primary skin fibroblasts of a reference $F A N C B$ patient (24). As shown in Figure 4 , the FA typical $G_{2}$ arrest can be recognized in the non-transduced and mock-transduced $F A N C B$-deficient cells as well as control $F A N C G$-deficient cells after exposure to MMC. However, neither the non-FA control cells nor the $F A N C B$-deficient cells expressed the FANCB wildtype or G335E proteins. This result clearly demonstrated that the missense FANCB protein p.G335E is able to completely correct the FA-typical cell cycle arrest and therefore in sharp contrast to all four prediction algorithms has normal functions comparable to the wildtype protein.

Reliable and clinically usable classification of variants of unknown significance (VUS) is a major challenge for rare sequence alterations in both germline as well as tumor DNA. The in silico online prediction tools can be helpful, however confirmation needs to be obtained in clinical data sets and also by functional studies. A remarkable failure of online prediction tools was reported for $S L X 4 / F A N C P$. Bakker et al. reported the presence of 39 missense variants in 729 BRCA1/2-negative breast cancer cases (56). Two rare ones were predicted by at least two out of three online prediction programs to be pathogenic. Shah et al. analyzed 738 BRCA1/2-negative patients from breast cancer pedigrees with at least two or more family members affected (57). From 51 missense variants, 22 were predicted to be damaging by Polyphen2. Both groups then tested seven of their most likely pathogenic mutants for functional activity after expression in genetically $S L X 4$ deficient cells and could not detect any impairment in the cellular response to mitomycin $\mathrm{C}$, demonstrating that the predictions were simply wrong $(56,57)$.

All four prediction programs erroneously classified the FANCB p.G335E amino acid alteration as pathogeneic and associated with loss-of-function. However, strong phenotypic evidence - independent from any functional testing - made it highly unlikely that this classification was correct. As men only have one functional $F A N C B$ allele on their single $\mathrm{X}$ chromosome, any germline sequence alteration associated with a pronounced functional deficit would make these men $F A N C B$ patients with the strong phenotypic characteristics of the FA-B complementation group (33) including severe congenital abnormalities and allogeneic hematopoietic stem cell transplantation before adulthood $(20,58,59)$.

In conclusion, FANCB cannot be a major inherited susceptibility factor for male HNSCCs or other male cancer. In fact, for the classification of inherited missense variants in X-chromosomal genes with a clear clinical phenotype, occurrence in 'homozygous' state in healthy men (or females) should automatically lead to the classification as nonpathogenic. In contrast, the role of FANCB as an inherited heterozygous risk factor in females is much less clear. Importantly, due to the strong selection disadvantage of $F A N C B$-deficient cells, female heterozygous mutation carriers will inactivate the $\mathrm{X}$-chromosome with the mutant $F A N C B$ allele in all of the mature hematopoietic cells in the peripheral blood (33). It appears likely that this also occurs in other cells in the body, however so far this has not formally been tested in female $F A N C B$ mutation carriers. Here, it would be very interesting to study how complete the inactivation of the defective $F A N C B$ locus occurs in cells of different organs and origin and whether tumors might arise in female $F A N C B$ mutation carriers over their lifetime due to the hypermutability in cells if the inactivation is incomplete or the healthy X-chromosome inactivated. In order to ultimately exclude $F A N C B$ germline mutations as a risk factor in HNSCCs, the next step is to selectively screen missense alterations in FANCB that only occur in a heterozygous state in females but never in males for activity in our overexpression system.

\section{Acknowledgements}

The Authors would like to thank the HNSCC patients for participating and providing support for these studies. The Authors would like to thank the patients and their family for their interest in our research over the years. The Authors are indebted to Stephanie L. Kelich and Nadine Lottmann for expert technical assistance. This work was funded, in part, by the DFG SPP 1230 and the Deutsche Jose Carreras Leukämie Stiftung e.V. (to HH), the Forschungskommission of the Medical Faculty and the Strategische Forschungsverbund of the Heinrich Heine University (to $\mathrm{CW}$ and $\mathrm{KR}$ ) and the Seventh Framework Programme and the Horizon 2020 Programme of the European Commission (611425, to KS).

\section{References}

1 O'Rorke MA, Ellison MV, Murray LJ, Moran M, James J and Anderson LA: Human papillomavirus related head and neck cancer survival: a systematic review and meta-analysis. Oral oncology 48: 1191-1201, 2012.

2 Michmerhuizen NL, Birkeland AC, Bradford CR and Brenner JC: Genetic determinants in head and neck squamous cell carcinoma and their influence on global personalized medicine. Genes Cancer 7: 182-200, 2016.

3 Zou AE, Zheng H, Saad MA, Rahimy M, Ku J, Kuo SZ, Honda TK, Wang-Rodriguez J, Xuan Y, Korrapati A, Yu V, Singh P, Grandis JR, King CC, Lippman SM, Wang XQ, Hinton A and Ongkeko WM: The non-coding landscape of head and neck squamous cell carcinoma. Oncotarget 7: 51211-51222, 2016.

4 Baltaci E, Karaman E, Dalay N and Buyru N: Analysis of gene copy number changes in head and neck cancer. Clin Otolaryngol, 2016. doi: 10.1111/coa.12686. [Epub ahead of print]

5 Siegel RL, Miller KD and Jemal A: Cancer statistics, 2016. CA Cancer J Clin 66: 7-30, 2016.

6 Califano J, van der Riet P, Westra W, Nawroz H, Clayman G, Piantadosi S, Corio R, Lee D, Greenberg B, Koch W and Sidransky D: Genetic progression model for head and neck cancer: implications for field cancerization. Cancer Res 56: 2488-2492, 1996. 
7 Zhou G, Liu Z and Myers JN: TP53 Mutations in head and neck squamous cell carcinoma and their impact on disease progression and treatment response. J Cell Biochem 117: 2682-2692, 2016.

8 Balz V, Scheckenbach K, Gotte K, Bockmuhl U, Petersen I and Bier $\mathrm{H}$ : Is the p53 inactivation frequency in squamous cell carcinomas of the head and neck underestimated? Analysis of p53 exons 2-11 and human papillomavirus 16/18 E6 transcripts in 123 unselected tumor specimens. Cancer Res 63: 1188-1191, 2003.

9 Cancer Genome Atlas Research N: Comprehensive genomic characterization of squamous cell lung cancers. Nature 489: 519525,2012 .

10 Lang JC, Borchers J, Danahey D, Smith S, Stover DG, Agrawal A, Malone JP, Schuller DE, Weghorst CM, Holinga AJ, Lingam K, Patel CR and Esham B: Mutational status of overexpressed p16 in head and neck cancer: evidence for germline mutation of p16/p14ARF. Int J Oncol 21: 401-408, 2002.

11 Cabanillas R, Astudillo A, Valle M, de la Rosa J, Alvarez R, Duran NS and Cadinanos J: Novel germline CDKN2A mutation associated with head and neck squamous cell carcinomas and melanomas. Head Neck 35: E80-84, 2013.

$12 \mathrm{Yu}$ KK, Zanation AM, Moss JR and Yarbrough WG: Familial head and neck cancer: molecular analysis of a new clinical entity. The Laryngoscope 112: 1587-1593, 2002.

13 Sabir M, Baig RM, Mahjabeen I and Kayani MA: Novel germline CDK4 mutations in patients with head and neck cancer. Hered Cancer Clin Pract 10: 11, 2012.

14 Pai SI, Wu GS, Ozoren N, Wu L, Jen J, Sidransky D and ElDeiry WS: Rare loss-of-function mutation of a death receptor gene in head and neck cancer. Cancer Res 58: 3513-3518, 1998.

15 Shao X, Tandon R, Samara G, Kanki H, Yano H, Close LG, Parsons $\mathrm{R}$ and Sato T: Mutational analysis of the PTEN gene in head and neck squamous cell carcinoma. Int J Cancer 77: 684-688, 1998.

16 Schwentner I, Witsch-Baumgartner M, Sprinzl GM, Krugmann J, Tzankov A, Jank S, Zwierzina $\mathrm{H}$ and Loeffler-Ragg J: Identification of the rare EGFR mutation p.G796S as somatic and germline mutation in white patients with squamous cell carcinoma of the head and neck. Head Neck 30: 1040-1044, 2008.

17 Scheckenbach K, Baldus SE, Balz V, Freund M, Pakropa P, Sproll C, Schafer KL, Wagenmann M, Schipper J and Hanenberg $\mathrm{H}$ : RAD51C - a new human cancer susceptibility gene for sporadic squamous cell carcinoma of the head and neck (HNSCC). Oral Oncol 50: 196-199, 2014.

18 Stransky N, Egloff AM, Tward AD, Kostic AD, Cibulskis K, Sivachenko A, Kryukov GV, Lawrence MS, Sougnez C, McKenna A, Shefler E, Ramos AH, Stojanov P, Carter SL, Voet D, Cortes ML, Auclair D, Berger MF, Saksena G, Guiducci C, Onofrio RC, Parkin M, Romkes M, Weissfeld JL, Seethala RR, Wang L, Rangel-Escareno C, Fernandez-Lopez JC, HidalgoMiranda A, Melendez-Zajgla J, Winckler W, Ardlie K, Gabriel SB, Meyerson M, Lander ES, Getz G, Golub TR, Garraway LA and Grandis JR: The mutational landscape of head and neck squamous cell carcinoma. Science 333: 1157-1160, 2011.

19 Antoniou AC, Casadei S, Heikkinen T, Barrowdale D, Pylkas K, Roberts J, Lee A, Subramanian D, De Leeneer K, Fostira F, Tomiak E, Neuhausen SL, Teo ZL, Khan S, Aittomaki K, Moilanen JS, Turnbull C, Seal S, Mannermaa A, Kallioniemi A, Lindeman GJ, Buys SS, Andrulis IL, Radice P, Tondini C, Manoukian S, Toland AE, Miron P, Weitzel JN, Domchek SM, Poppe B, Claes KB, Yannoukakos D, Concannon P, Bernstein JL, James PA, Easton DF, Goldgar DE, Hopper JL, Rahman N, Peterlongo P,
Nevanlinna H, King MC, Couch FJ, Southey MC, Winqvist R, Foulkes WD and Tischkowitz M: Breast-cancer risk in families with mutations in PALB2. N Engl J Med 371: 497-506, 2014.

20 Kutler DI, Singh B, Satagopan J, Batish SD, Berwick M, Giampietro PF, Hanenberg H and Auerbach AD: A 20-year perspective on the International Fanconi Anemia Registry (IFAR). Blood 101: 1249-1256, 2003.

21 Kennedy AW and Hart WR: Multiple squamous-cell carcinomas in Fanconi's anemia. Cancer 50: 811-814, 1982.

22 Rosenberg PS, Socie G, Alter BP and Gluckman E: Risk of head and neck squamous cell cancer and death in patients with Fanconi anemia who did and did not receive transplants. Blood 105: 67-73, 2005.

23 Kutler DI, Patel KR Auerbach AD, Kennedy J, Lach FP, Sanborn E, Cohen MA, Kuhel WI, and Smogorzewska A: Natural history and management of Fanconi anemia patients with head and neck cancer: A 10-year follow-up. Laryngoscope 126: 870-879, 2016.

24 Nalepa G, Enzor R, Sun Z, Marchal C, Park SJ, Yang Y, Tedeschi L, Kelich S, Hanenberg H and Clapp DW: Fanconi anemia signaling network regulates the spindle assembly checkpoint. J Clin Invest 123: 3839-3847, 2013.

25 Sumpter R, Jr., Sirasanagandla S, Fernandez AF, Wei Y, Dong X, Franco L, Zou Z, Marchal C, Lee MY, Clapp DW, Hanenberg $\mathrm{H}$ and Levine B: Fanconi anemia proteins function in mitophagy and immunity. Cell 165: 867-881, 2016.

26 Garbati MR, Hays LE, Rathbun RK, Jillette N, Chin K, Al-Dhalimy M, Agarwal A, Newell AE, Olson SB and Bagby GC Jr.: Cytokine overproduction and crosslinker hypersensitivity are unlinked in Fanconi anemia macrophages. J Leukoc Biol 99: 455-465, 2016.

27 Sarkar J and Liu Y: Fanconi anemia proteins in telomere maintenance. DNA Repair (Amst) 43: 107-112, 2016.

28 Barthelemy J, Hanenberg $\mathrm{H}$ and Leffak M: FANCJ is essential to maintain microsatellite structure genome-wide during replication stress. Nucl Acid Res 44: 6803-6816, 2016.

29 Michl J, Zimmer J and Tarsounas M: Interplay between Fanconi anemia and homologous recombination pathways in genome integrity. EMBO J 35: 909-923, 2016.

30 Ceccaldi R, Sarangi P and D'Andrea AD: The Fanconi anaemia pathway: new players and new functions. Nat Rev Mol Cell Biol 17: 337-349, 2016.

31 Park JY, Virts EL, Jankowska A, Wiek C, Othman M, Chakraborty SC, Vance GH, Alkuraya FS, Hanenberg H and Andreassen PR: Complementation of hypersensitivity to DNA interstrand crosslinking agents demonstrates that XRCC2 is a Fanconi anaemia gene. J Med Genet 53: 672-680, 2016.

32 Bluteau D, Masliah-Planchon J, Clairmont C, Rousseau A, Ceccaldi R, Dubois d'Enghien C, Bluteau O, Cuccuini W, Gachet S, Peffault de Latour R, Leblanc T, Socie G, Baruchel A, Stoppa-Lyonnet D, D'Andrea AD and Soulier J: Biallelic inactivation of REV7 is associated with Fanconi anemia. J Clin Invest 126: 3580-3584, 2016.

33 Meetei AR, Levitus M, Xue Y, Medhurst AL, Zwaan M, Ling C, Rooimans MA, Bier P, Hoatlin M, Pals G, de Winter JP, Wang $\mathrm{W}$ and Joenje $\mathrm{H}$ : X-linked inheritance of Fanconi anemia complementation group B. Nat Genet 36: 1219-1224, 2004.

34 Ameziane N, May P, Haitjema A, van de Vrugt HJ, van RossumFikkert SE, Ristic D, Williams GJ, Balk J, Rockx D, Li H, Rooimans MA, Oostra AB, Velleuer E, Dietrich R, Bleijerveld OB, Maarten Altelaar AF, Meijers-Heijboer H, Joenje H, Glusman G, Roach J, Hood L, Galas D, Wyman C, Balling R, den Dunnen 
J, de Winter JP, Kanaar R, Gelinas R and Dorsman JC: A novel Fanconi anaemia subtype associated with a dominant-negative mutation in RAD51. Nat Commun 6: 8829, 2015.

35 Wang AT, Kim T, Wagner JE, Conti BA, Lach FP, Huang AL, Molina H, Sanborn EM, Zierhut H, Cornes BK, Abhyankar A, Sougnez C, Gabriel SB, Auerbach AD, Kowalczykowski SC and Smogorzewska A: A Dominant Mutation in Human RAD51 Reveals Its Function in DNA Interstrand Crosslink Repair Independent of Homologous Recombination. Mol Cell 59: 478-490, 2015.

36 D'Andrea AD: Susceptibility pathways in Fanconi's anemia and breast cancer. N Engl J Med 362: 1909-1919, 2010.

37 Pennington KP and Swisher EM: Hereditary ovarian cancer: Beyond the usual suspects. Gynecol Oncol 124: 347-353, 2012.

38 Yang SY, Hsiung CN, Li YJ, Chang GC, Tsai YH, Chen KY, Huang MS, Su WC, Chen YM, Hsiung CA, Yang PC, Chen CJ, Wu PE, Yu JC, Shen CY and Hsu HM: Fanconi anemia genes in lung adenocarcinoma- a pathway-wide study on cancer susceptibility. J Biomed Sci 23: 23, 2016.

39 Kato Y, Alavattam KG, Sin HS, Meetei AR, Pang Q, Andreassen PR and Namekawa SH: FANCB is essential in the male germline and regulates $\mathrm{H} 3 \mathrm{~K} 9$ methylation on the sex chromosomes during meiosis. Hum Mol Genet 24: 5234-5249, 2015.

40 Wreesmann VB, Estilo C, Eisele DW, Singh B and Wang SJ: Down-regulation of Fanconi anemia genes in sporadic head and neck squamous cell carcinoma. ORL J Otorhino-laryngol Relat Spec 69: 218-225, 2007.

41 Smith IM, Mithani SK, Mydlarz WK, Chang SS and Califano JA: Inactivation of the tumor suppressor genes causing the hereditary syndromes predisposing to head and neck cancer via promoter hypermethylation in sporadic head and neck cancers. ORL J Otorhino-laryngol Relat Spec 72: 44-50, 2010.

42 Meindl A, Hellebrand H, Wiek C, Erven V, Wappenschmidt B, Niederacher D, Freund M, Lichtner P, Hartmann L, Schaal H, Ramser J, Honisch E, Kubisch C, Wichmann HE, Kast K, Deissler H, Engel C, Muller-Myhsok B, Neveling K, Kiechle M, Mathew CG, Schindler D, Schmutzler RK and Hanenberg H: Germline mutations in breast and ovarian cancer pedigrees establish RAD51C as a human cancer susceptibility gene. Nat Genet 42: 410-414, 2010.

43 Wiek C, Schmidt EM, Rollecke K, Freund M, Nakano M, Kelly EJ, Kaisers W, Yarov-Yarovoy V, Kramm CM, Rettie AE and Hanenberg $\mathrm{H}$ : Identification of amino acid determinants in CYP4B1 for optimal catalytic processing of 4-Ipomeanol. Biochem J 465: 103-114, 2015.

44 Roellecke K, Virts EL, Einholz R, Edson KZ, Altvater B, Rossig C, von Laer D, Scheckenbach K, Wagenmann M, Reinhardt D, Kramm CM, Rettie AE, Wiek C and Hanenberg H: Optimized human CYP4B1 in combination with the alkylator prodrug 4ipomeanol serves as a novel suicide gene system for adoptive Tcell therapies. Gene Ther 23: 615-626, 2016.

45 Virts EL, Jankowska A, Mackay C, Glaas MF, Wiek C, Kelich SL, Lottmann N, Kennedy FM, Marchal C, Lehnert E, Scharf RE, Dufour C, Lanciotti M, Farruggia P, Santoro A, Savasan S, Scheckenbach K, Schipper J, Wagenmann M, Lewis T, Leffak M, Farlow JL, Foroud TM, Honisch E, Niederacher D, Chakraborty SC, Vance GH, Pruss D, Timms KM, Lanchbury JS, Alpi AF and Hanenberg H: AluY-mediated germline deletion, duplication and somatic stem cell reversion in UBE2T defines a new subtype of Fanconi anemia. Hum Mol Genet 24: 5093$5108,2015$.
46 Gross M, Hanenberg H, Lobitz S, Friedl R, Herterich S, Dietrich R, Gruhn B, Schindler D and Hoehn H: Reverse mosaicism in Fanconi anemia: natural gene therapy via molecular selfcorrection. Cytogenet Genome Res 98: 126-135, 2002.

47 Hartmann L, Neveling K, Borkens S, Schneider H, Freund M, Grassman E, Theiss S, Wawer A, Burdach S, Auerbach AD, Schindler D, Hanenberg $\mathrm{H}$ and Schaal $\mathrm{H}$ : Correct mRNA processing at a mutant TT splice donor in FANCC ameliorates the clinical phenotype in patients and is enhanced by delivery of suppressor U1 snRNAs. Am J Hum Genet 87: 480-493, 2010.

48 Hanahan D and Weinberg RA: Hallmarks of cancer: the next generation. Cell 144: 646-674, 2011.

49 Lord CJ and Ashworth A: The DNA damage response and cancer therapy. Nature 481: 287-294, 2012.

50 Hashimoto S, Anai $\mathrm{H}$ and Hanada K: Mechanisms of interstrand DNA crosslink repair and human disorders. Genes Environ 38 : 9, 2016.

51 van Twest S, Murphy VJ, Hodson C, Tan W, Swuec P, O'Rourke JJ, Heierhorst J, Crismani W and Deans AJ: Mechanism of ubiquitination and deubiquitination in the Fanconi anemia pathway. Mol Cell 65: 247-259, 2017.

52 Nomura $\mathrm{Y}$, Adachi $\mathrm{N}$ and Koyama H: Human Mus81 and FANCB independently contribute to repair of DNA damage during replication. Genes Cells 12: 1111-1122, 2007.

$53 \mathrm{Du}$ W, Amarachintha S, Erden O, Wilson A, Meetei AR, Andreassen PR, Namekawa SH and Pang Q: Fancb deficiency impairs hematopoietic stem cell function. Sci Rep 5: 18127, 2015.

54 Jamsai D, O'Connor AE, O'Donnell L, Lo JC and O'Bryan MK: Uncoupling of transcription and translation of Fanconi anemia (FANC) complex proteins during spermatogenesis. Spermatogenesis 5: e979061, 2015.

55 Garcia MJ, Fernandez V, Osorio A, Barroso A, Llort G, Lazaro C, Blanco I, Caldes T, de la Hoya M, Ramon YCT, Alonso C, Tejada MI, San Roman C, Robles-Diaz L, Urioste M and Benitez J: Analysis of FANCB and FANCN/PALB2 fanconi anemia genes in BRCA1/2-negative Spanish breast cancer families. Breast Cancer Res Treat 113: 545-551, 2009.

56 Bakker JL, van Mil SE, Crossan G, Sabbaghian N, De Leeneer K, Poppe B, Adank M, Gille H, Verheul H, Meijers-Heijboer H, de Winter JP, Claes K, Tischkowitz M and Waisfisz Q: Analysis of the novel Fanconi anemia gene SLX4/FANCP in familial breast cancer cases. Hum Mutat 34: 70-73, 2013.

57 Shah S, Kim Y, Ostrovnaya I, Murali R, Schrader KA, Lach FP, Sarrel K, Rau-Murthy R, Hansen N, Zhang L, Kirchhoff T, Stadler Z, Robson M, Vijai J, Offit K and Smogorzewska A: Assessment of SLX4 mutations in hereditary breast cancers. PloS one 8: e66961, 2013.

58 Holden ST, Cox JJ, Kesterton I, Thomas NS, Carr C and Woods CG: Fanconi anaemia complementation group B presenting as $\mathrm{X}$ linked VACTERL with hydrocephalus syndrome. J Med Genet 43: 750-754, 2006.

59 Alter BP and Rosenberg PS: VACTERL-H Association and Fanconi Anemia. Mol Syndromol 4: 87-93, 2013.

Received December 17, 2017

Revised January 18, 2018

Accepted January 23, 2018 